\title{
IfIISGUCDERGI.ORG
}

"İȘ, GÜC̣" ENDÜSTRi ilLișKiLERI VE INSAN KAYNAKLARI DERGISi

"IS, GUC" INDUSTRIAL RELATIONS AND HUMAN RESOURCES JOURNAL

\section{The Effectiveness And Efficiency Of Trade Unions In The Labour Market Of Turkey}

\author{
M. Kemal ÖKE \\ Assoc.Prof. Dr., Abant Izzet Baysal University
}

Ekim/October 2009, Cilt/Vol: 11, Say1/Num: 6, Page: 39-55

ISSN: 1303-2860, DOI: 10.4026/1303-2860.2009.0131.x

Makalenin on-line kopyasına erişmek için:

http://www.isgucdergi.org/?p=makale\&id=405\&cilt=11\&sayi=6\&yil=2009

To reach the on-line copy of article:

http://www.isguc.org/?p=article\&id=405\&vol=11\&num=6\&year=2009

Makale İçin İletişim/Correspondence to:

Yazarların e-posta adresleri verilmiştir. Writers e-mail was given for contact. 
(C) 2000- 2009

"İşGüç̧" Endüstri İlişkileri ve İnsan Kaynakları Dergisi

"İşGǚç" Industrial Relations and Human Resources Journal

Ekim/October 2009, Cilt/Vol: 11, Say1/Num: 6

ISSN: 1303-2860, DOI: 10.4026/1303-2860.2009.0131.x

Editör/Editor-in-Chief

Aşkın Keser (Kocaeli University)

Editör Yardımcıları/Co-Editors

K.Ahmet Sevimli (Uludağ University)

Gözde Yulmaz (Kocaeli University)

Uygulama/Design

Yusuf Budak (Kocaeli Universtiy)

\author{
Yayin Kurulu / Publishing Committee \\ Dr.Zerrin Firat (Uludă̆ University) \\ Doç.Dr.Aşkın Keser (Kocaeli University) \\ Prof.Dr.Ahmet Selamoğlu (Kocaeli University) \\ Yrd.Doç.Dr.Ahmet Sevimli (Uludağ University) \\ Yrd.Doç.Dr.Abdulkadir Şenkal (Kocaeli University) \\ Yrd.Doç.Dr.Gözde Yilmaz (Kocaeli University) \\ Dr.Memet Zencirkıran (Uludağ University)
}

Uluslararası Danışma Kurulu / International Advisory Board

Prof.Dr.Ronald Burke (York University-Kanada)

Assoc.Prof.Dr.Glenn Dawes (James Cook University-Avustralya)

Prof.Dr.Jan Dul (Erasmus University-Hollanda)

Prof.Dr.Alev Efendioğlu (University of San Francisco-ABD)

Prof.Dr.Adrian Furnham (University College London-İngiltere)

Prof.Dr.Alan Geare (University of Otago- Yeni Zellanda)

Prof.Dr. Ricky Griffin (TAMU-Texas AEM University-ABD)

Assoc. Prof. Dr. Diana Lipinskiene (Kaunos University-Litvanya)

Prof.Dr.George Manning (Northern Kentucky University-ABD)

Prof. Dr. William (L.) Murray (University of San Francisco-ABD)

Prof.Dr.Mustafa Özbilgin (University of East Anglia-UK)

Assoc. Prof. Owen Stanley (James Cook University-Avustralya)

Prof.Dr.Işık Urla Zeytinoğlu (McMaster University-Kanada)

Danışma Kurulu / National Advisory Board

Prof.Dr.Yusuf Alper (Uludağ University)

Prof.Dr.Veysel Bozkurt (Uludağ University)

Prof.Dr.Toker Dereli (Işık University)

Prof.Dr.Nihat Erdoğmuş (Kocaeli University)

Prof.Dr.Ahmet Makal (Ankara University)

Prof.Dr.Ahmet Selamoğlu (Kocaeli University)

Prof.Dr.Nadir Suğur (Anadolu University)

Prof.Dr.Nursel Telman (Maltepe University)

Prof.Dr.Cavide Uyargil (İstanbul University)

Prof.Dr.Engin Yildırım (Sakarya University)

Doç.Dr.Arzu Wasti (Sabancı University)

Dergide yayınlanan yazılardaki görüşler ve bu konudaki sorumluluk yazarlarma aittir.

Yayınlanan eserlerde yer alan tüm içerik kaynak gösterilmeden kullanılamaz.

All the opinions written in articles are under responsibilities of the outhors.

None of the contents published can't be used without being cited. 


\title{
The Effectiveness And Efficiency Of Trade Unions In The Labour Market Of Turkey
}

\author{
M. Kemal ÖKE \\ Assoc.Prof. Dr., Abant Izzet Baysal University
}

\begin{abstract}
:
Since some decades many things have been changed such as culture, attitude, behaviour, structures in the economy and society naturally these process leads to industrial relations, but nothing has been changed in the field of structure and policy and stragedy of trade unions. As we remember one of challenging vawe has been realised during the Keynesian Age which called Post Fordism. This wave affected labour deeply, because new wave swepeed out blue colour workers at the manifacture sector. This was first and great shock for trade unions. Because not only in Turkey but also in European Countries blue colour workers were locomotive of trade union mouvement middle of the 20th. Century. During the 1980's the other big shock realised for trade unions with neo-liberal policies. During this age not only blue colour workers but also public sector workers decreased drastically. At the end when we having 21st. Century unions are facing deep economic crise such as 1929. Even though this kind of transformation, technological changes, changed labour demand pattern, changed culture related to solidarity and huge threats still unions keeping old wine in the old bottle. There is no new policies, new strategies and tactics. Nobody knows is this sustainable. But it looks this is end of the tunnel for traditional trade union perceptions.
\end{abstract}

Keywords: Union effectiveness, efficiency, social dialogue, Union's role in the labour market 


\section{INTRODUCTION}

The aim of this research to analysis situation of trade unions in the labour market. Specificly targeting elaborate the capacity of trade unions and underlying weaknesses, strenghness of unions in Turkey. In this sense trying to make compative analysis with some EU countries in the field of some industrial relations indicator. Especially in the field of representation at work place, at sector level and national level. Finally trying to explore effectiveness and efficiency of unions and indicating how to destroy barriers in order to be more functional. At the end discussing the role of the unions in the democratic atmosphere.

\subsection{Defination}

In this research focusing on labour trade unions. In the terminologic aspect considering only labour unions as trade union. On the other side called employer unions as "employer association". According to our understanding employer associations take part as union incorrectly in Turkish regulation. Almost all over the world only labour unions codes as trade union in the terminology of industrial relations.

\section{INDUSTRIAL RELATIONS IN TURKEY AND EASTERN EUROPEAN COUNTRIES}

\subsection{Workplace Industrial Relations in Turkey}

One of the main characteristic is; unionisation and institutionalised relations have been influenced by frequent political and legal changes. In addition to its decisive role in legislation, the state has played a dominant role in industrial relations as an employer because of the high number and large size of state enterprises. As a consequence, trade unions have become more and more dependent on the state to come up with solutions to their problems (Koray, 1992).

The other main characteristic is low rate of labour force in population. Naturally this structure reflect to employment. Therefore almost one-third of population take place in employment in Turkey; in EU countres this figure about half of the population or less half of the population. In other words comparatively limited number take place in labour force.

Table 1

Structure of Labour Force in Turkey 1950-2004 (\%)

\begin{tabular}{|c|c|c|c|c|}
\hline Years & 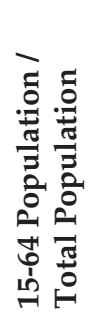 & 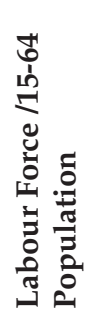 & 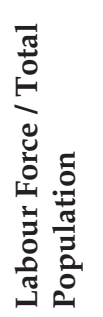 & 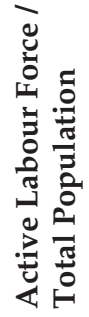 \\
\hline 1950 & 57,06 & 80,88 & 46,15 & 45,52 \\
\hline 2000 & 64,61 & 52,95 & 34,21 & 30,50 \\
\hline 2004 & 65,50 & 51,99 & 34,06 & 30,90 \\
\hline 2006 & 70.48 & 48.36 & 34.47 & 31.31 \\
\hline
\end{tabular}

Thirdly main charecteristic is scale of enterprises. Very large magority of enterprises employ few workers. Medium size or big enterprises are very limited. This is one of the direct obstacles in order to be intitutionalize of labour market in Turkey.

Table 2

Company Size in Europe and Turkey (\%)

\begin{tabular}{|l|c|c|c|}
\hline Company size & ACC12 & EU15 & Turkey \\
\hline 1 person & 11 & 11 & 25 \\
\hline 2-4 people & 21 & 15 & 50 \\
\hline $5-9$ people & 13 & 12 & 13 \\
\hline 10-49 people & 25 & 26 & 8 \\
\hline $50-99$ people & 8 & 9 & 2 \\
\hline 100-249 people & 7 & 9 & 1 \\
\hline 250-499 people & 4 & 5 & \\
\hline $50-99$ people & 7 & 10 & 1 \\
\hline not specified & 5 & 3 & \\
\hline 1-4 people & 32 & 26 & 75 \\
\hline
\end{tabular}


The other characteristic is fragmented structure in labour market in Turkey such as some European countries. This fragmented structure have some reasons. One of the reason is regulation. According to Trade Union Act (2821) over all economy constitute 28 different sector. In this circumstance in the labour market will be operate at least 28 union. Additionaly Trade union act exclude public servant. Therefore different statue and different unions exist for public servant. Secondly trade union mouvement and culture based on "small and mine" consept. Union leaders never attempt to merger with other unions in order to create big and strong union such as UNISON in United Kingdom, Ver.di in Germany etc. Thirdly there is serious competition among the union, time and energy vasting endlessly towards to each other, this process eroding all synergy of unions and putting obstacles design new strategy for the future. Lastly structure of labour market based on fragmented core and peripherial labour.

Finally the last main characteristics of labour relations are their segmentation and their dualistic structure: on the one hand are 'informalised' and marginalised workers who are non-unionised and low wages due to uncovered by collective bargaining; on the other hand is a very small percentage of employees who are covered by collective bargaining as members of a trade union with reasonable wages and relatively good working conditions. More than hundred trade unions share this small percentage and compete each other in order to survive(Öke, 2005).

\subsection{Workplace Industrial Relations in Eastern European Countries}

East European countries exhibit different characteristics and responses to broadly similar problems and challenges like Turkey. The industrial relations of Turkey has diffeent characteristic but has very similar problems with Eastern European Countries. These are summarised as follow:
1)Loss of significance of presence of trade unions at local level as a result of dramatic membership losses following privatization and new start-ups, in particular of SME's and greater pressure from employers. Union can no longer often effectively deliver their productive function in the magority of workplaces.

2)This is connected in some cases with a very low level of collective bargaining coverage due to the lack of branch-level agreements. Most employee are covered by individual contracts of employment.

3)Management has persisted with the ideas and practise of inherited approaches and traditional organizational cultures. At the same time, here is a broad spectrum of behaviour, ranging from "walking cane" capitalism and neo-paternalism to US styles and more participative human resource approaches.

4)What was certainly helpful during restructuring was the inherited strong legal protection against dismissals - since weakened in the wake of liberalization and globalization (including under pressure from the World Bank and IMF). The consequences are increased insecurity, ever-widening areas of the economy in which there are no trade unions or other forms of employee representation, and the loss of trade unions' capacity to exert pressure, organise solidarity and take industrial action.

5)At the same time, some more innovative managers regret the lack of capable partners at the workplace to help steer change and provide for a means of resolving the problems this entails with less friction. New management systems and corporate cultures require new forms of industrial relations, with more scope for employee participaion and the use of their creative potential.

6)The experience of EWC's with their specific foms of social dialogue in multinational companies, presuppose effective co-operation and coherence on the employee side that in turn feeds back on management behaviour. 
7)All the above, together with the required approximation of national laws with European law, has led to a situation in which work councils, as a second legally-based form of employee representation, have been able to be astablished within a southern group (Slovenia, Hungary and more recently Slovakia) of the new member states, whereas in the remainder- mainly northern countries- the social partners have adopted a more defensive or hesitant stance.(Kohl-Platzer, 2004)

\section{UNION DENSITY AND COLLECTIVE BARGAIN COVERAGE}

One of the most important indicator of social dialogue and institutionalize of labour relation is union density and collective bargain coverage. Altough major problem is low rate union density and weak connection between density and collective bargaining coverage in Turkey. According to the latest statistics of the Labour Ministry (January 2009 for workers May 2008 for public employee), union density is as shown in Table:

Table 3

\section{Union density according to statue}

\begin{tabular}{|l|l|}
\hline Total number of wor- & Total number of civil \\
kers who are eligible & servants who are eli- \\
to be union members: & gible to be union \\
5434433 & members: 1691299 \\
\hline Total number of & Total number of \\
union members: & union members: \\
3205662 & 930397 \\
\hline Union density: 59\% & Union density is 55 \\
\hline
\end{tabular}

Source: Labour Ministry statistics

In fact total number of union members are totally fictive which indicated in the official statistic, real number is much lower than this. So union density for workers about $\% 20$ maybe less than this percentage. Othervise there is no reason of the gap between more than 3 million member of union and less than 1 million benefitting workers from collective agreement.

\section{Table 4}

\section{Collective Bargainin Coverage And} General Extension of Agreements in the New EU Member States

(as \% of employees of a country)

\begin{tabular}{|l|c|c}
\hline Country & $\begin{array}{c}\text { \% of workers } \\
\text { covered by } \\
\text { collective } \\
\text { agreement } \\
\text { Slovenia }\end{array}$ & $\begin{array}{c}\text { Sectoral agreements } \\
\text { with binding force for all } \\
\text { employers }\end{array}$ \\
\hline Slovakia & 100 & all agreements \\
\hline Hungary & 50 & possible \\
\hline Czech Republic & 32 & rare exception \\
\hline Poland & 35 & frequent since 2000 \\
Estonia & 22 & $\begin{array}{c}\text { possible since 2000 } \\
\text { possible since 2000 } \\
\text { possible since 2002 }\end{array}$ \\
\hline Latvia & 20 & $\begin{array}{c}\text { possible since 2003, } \\
\text { but no application }\end{array}$ \\
\hline Lithuania & 15 & $\begin{array}{c}\text { possible by law, } \\
\text { but no application }\end{array}$ \\
\hline Turkey & 10 &
\end{tabular}

Source: Heribert Kohl, Social Dialogue Indicators: Benchmarking Turkey towards EU Workshop Ankara, 2007

The other issue is extending of collective agreement to all sector. In some of the Eastern countries there are some mechanisms and practice in this manner contrary in Turkey existing legal opportunity but there is no application at all. Even though having very short tradation in the maket economy and industrial relation system some mechanisms take place in these countries unfortunately there is not any practice in the field of extend of collective agreement in Turkey.

\section{CAPACITIES OF TRADE UNIONS}

Most of the unions are organised on a sector or occupational base throughout the EU. Traditionally, blue-collar unions were the most powerful, but they are loosing ground everywhere in Europe and white-collar unions or public sector unions are getting more important. In a lot of the EU Member states unions exist which are not part of a confederation, but are autonomous. Often these autonomous unions organise professional and managerial staff or certain rural regions.

Austria, Ireland, Latvia, Slovakia and the UK and to a lesser extent Germany, the Czech Republic have only one confederation, which unites these unions. In Southern co- 
untries like Greece, Portugal and Spain only two main confederations are active. Unions in France, Hungary, Italy and Slovenia have a rather complicated and fragmented confederate structure. In Greece, Ireland, Poland and the UK the (main) confederation is composed of a fragmented network of affiliated trade unions, which can be organised on the company, occupational or local branch level. In other countries, the union structure is more and more dominated by large 'superunions', like GPA in Austria, Verdi in Germany and FNV-Bondgenoten in the Netherlands.

Splits at the confederate level throughout the EU are very often based on political and/or religious divisions. Exceptions are the Nordic countries (Denmark, Finland, and Sweden). Confederations in these nations are organised on an occupational base. In countries like Estonia, Greece, Malta and Slovenia the divide between public and private sector is important to distinguish the confederations. Socialist or social democratic confederations are in the countries with several trade union peak organisations most of the time dominant. An exception is Belgium with its strong Christian trade union. Confederations of communist origin are still very important in the South (Italy, Spain, Portugal and to a lesser extent France). Nonetheless, an overall pattern is a growing distance between trade unions and their counterparts in the political party spectrum and vice versa.(Gyes and others, 2006)

The division between the unions and confederations based on political leaning in Turkey as well as in EU countries but in some cases religous might be reason to support the union. Additionally union strategy and 1deology might be reason of division. Meanwhile sectoral organization and other factors could be functional.

Ditribution of union confederation and reason of the division indicate as in Table 5 in EU countries.

\subsection{Internal Factors Related to Lack of Ca- pacity of Turkish Trade Unions}

In this chapter analiysing capacity of trade union. Mainly two factors leads capacity of unions. One of them internal factors the other one is external factors. What is the internal factors which might be lead effectiveness of unions? Internal factor can be summarize as follow; this chapter claims to elobarete unions' capacity problems and search existing any connection among the lack of capacity and effectiveness of Turkish Unions. Capacities will be handled in three aspect. These are organizational capacity, personnel capacity, financial capacity.

\subsubsection{Organizational Capacity}

Capacity building of social dialogue needs; power and efficiency of social partner organisations. This mean that; strong central confederations; centralisation; co-ordination; representativeness; acknowledgement as partner; multi-level collective bargaining; higher coverage of agreements; influence on political decisions; influence on public opinion; presence in media; good image in the public; attractiveness and recruitment; national standards of legal, economic and social framework (Hülsmann-Kohl, 2006)

Trade unions and confederations are well organized institutions in Turkey. However due to informel economy, thresholds for collective bargain and lack of culture of social dialogue emerge constrains for trade unions in order to be more effective. First of all, informel economy and size of SMEs are crucial problems and they are creating hard task to combat in short term. Secondly thresholds putting barriers for trade union activities. According to legislation at the first stage union should represent ten percent of the total number of workers who work at the sector; at the second stage union should represent magority in other words number of the half of workers plus one at the workplace. These thresholds create limitations for trade unions and putting barriers to reach the collective agreement (Öke, 2006).

One of the indicator of institutionalize is 
Table 5

Ditribution of Union Confederation and Reason of the Division in EU Countries

\begin{tabular}{|c|c|c|c|c|c|c|}
\hline & $\mathrm{N}^{\circ}$ & Confederations & $\begin{array}{l}\text { Main division between con- } \\
\text { federations }\end{array}$ & $\begin{array}{l}\text { Unions } \\
\text { of } \\
\text { largest }\end{array}$ & $\begin{array}{l}\text { Main } \\
\text { division } \\
\text { affiliates }\end{array}$ & Remarks \\
\hline $\mathrm{AT}$ & 1 & ÖGB & & 13 & Sector/status & $\begin{array}{l}\text { Political factions as other organisa- } \\
\text { tional pillar }\end{array}$ \\
\hline $\mathrm{BE}$ & 3 & $\begin{array}{l}\text { ACV-CSC; ABVV-FGTB; } \\
\text { ACLVB-CGSLB }\end{array}$ & Political & 13 & Sector/status & Christian trade union the largest \\
\hline $\mathrm{CY}$ & 4 & $\begin{array}{l}\text { PEO; SEK; DEOK; POAS } \\
\text { PEO }\end{array}$ & Political & 8 & Sector & \\
\hline $\mathrm{CZ}$ & $1+3$ & $\begin{array}{l}\text { CMKOS; ASO; KUK; CMS; } \\
\mathrm{KOK}\end{array}$ & $\begin{array}{l}\text { Political; religious; regional; } \\
\text { occupational }\end{array}$ & 33 & Sector & One dominant confederation \\
\hline DK & 4 & LO; FTF; FR; AC & Occupation & $18+7$ & $\begin{array}{l}\text { Occupation/s } \\
\text { ector }\end{array}$ & \\
\hline EE & 3 & EAKL; TALO; ETMAKL & $\begin{array}{l}\text { Macro-sector/status/profes- } \\
\text { sion }\end{array}$ & 18 & Sector & $\begin{array}{l}\text { Rural workers in a separate small } \\
\text { federation }\end{array}$ \\
\hline FI & 3 & SAK; STTK; AKAVA & Occupation & 23 & Sector & \\
\hline FR & $5+2$ & $\begin{array}{l}\text { CGT; CFDT; CGT-FO; } \\
\text { CFTC; CFE-CGC + UNSA } \\
\& \text { G10-SUD }\end{array}$ & $\begin{array}{l}\text { Political, religious \& occupa- } \\
\text { tional (status) }\end{array}$ & 20 & Sector & $\begin{array}{l}\text { 5representative confederations } \\
\text { and } 2 \text { new one pushing for natio- } \\
\text { nal recognition }\end{array}$ \\
\hline $\mathrm{DE}$ & $1+2$ & DGB; CGB; DBB & Macro-sector; religious & 8 & Sector & $\begin{array}{l}\text { CGB and DBB are only small; } \\
\text { Verdi \& IG Metall important }\end{array}$ \\
\hline EL & 2 & GSEE; ADEDY & Public/private & 62 & $\begin{array}{l}\text { Occupation/s } \\
\text { ector }\end{array}$ & $\begin{array}{l}\text { Public and private union, planning } \\
\text { merger }\end{array}$ \\
\hline $\mathrm{HU}$ & 5 & $\begin{array}{l}\text { MSZOSZ; SZEF-ESZT } \\
\text { unió; LIGA; MOSZ; } \\
\text { ASZSZ }\end{array}$ & Macro-sector; political & 36 & $\begin{array}{l}\text { Sector; } \\
\text { branch, pro- } \\
\text { fession }\end{array}$ & $\begin{array}{l}\text { The union of SZEF-ESZT union is } \\
\text { only a cooperation framework, but } \\
\text { not a formal merger. }\end{array}$ \\
\hline IE & 1 & ICTU & & 60 & $\begin{array}{l}\text { Occupation/s } \\
\text { ector }\end{array}$ & $\begin{array}{l}\text { Trade unions with members in } \\
\text { Northern Ireland and affiliation } \\
\text { with UK unions }\end{array}$ \\
\hline IT & $3+8$ & $\begin{array}{l}\text { CGIL; CISL; UIL and other } \\
\text { smaller peak organisations }\end{array}$ & Political; religious & 15 & Sector & $\begin{array}{l}\text { Autonomous unions and regional } \\
\text { unions active }\end{array}$ \\
\hline $\mathrm{LV}$ & 1 & LBAS & & 26 & Sector & Restructuring \\
\hline $\mathrm{LT}$ & 3 & LPSK; Soldarumas; LDF & Political; religious & 25 & Sector & Independent trade unions active \\
\hline LU & 3 & $\begin{array}{l}\text { OGB-L; LCBG; } \\
\text { ALEBA/UEP-NGL-SNEP }\end{array}$ & Political; religious; status & 16 & Sector & $\begin{array}{l}\text { Merger of white-collar unions in } \\
\text { third confederation }\end{array}$ \\
\hline MT & 2 & GWU; CMTU & $\begin{array}{l}\text { To some extent private/pub- } \\
\text { lic }\end{array}$ & 7 & Sector & Weak confederations \\
\hline NL & 3 & FNV; CNV; MHP & $\begin{array}{l}\text { Political, religious, occupa- } \\
\text { tional status }\end{array}$ & 15 & Sector & $\begin{array}{l}\text { FNV-Bondgenoten as super-union } \\
\text { in the private sector }\end{array}$ \\
\hline PL & 3 & $\begin{array}{l}\text { OPZZ; NSZZ Solidarnosc; } \\
\text { FZZ }\end{array}$ & Political & 102 & $\begin{array}{l}\text { Sector, local } \\
\text { branch }\end{array}$ & $\begin{array}{l}\text { New third federation which wants } \\
\text { to be politically neutral }\end{array}$ \\
\hline PT & 2 & CGTP; UGT & Political & $15+29$ & Sector+region & $\begin{array}{l}28 \text { sector federations \& } 39 \text { regional } \\
\text { branches registered law }\end{array}$ \\
\hline SK & 1 & $\mathrm{KOZ}$ & & 37 & Sector & $\begin{array}{l}\text { Also very small Christian trade } \\
\text { union federation }\end{array}$ \\
\hline SI & 6 & $\begin{array}{l}\text { ZSSS; KNSS-Indepen- } \\
\text { dence; Pergam; Konfedera- } \\
\text { cija'90; Alternativa; } \\
\text { Solidarity }\end{array}$ & Mainly private/public & & & $\begin{array}{l}\text { Two newpeaks established re- } \\
\text { cently (Alternativa \& Solidarity) in } \\
\text { the railway sector }\end{array}$ \\
\hline ES & 2 & CC.OO; UGT & Political & 12 & Sector & Equal strength \\
\hline SE & 3 & LO; TCO; SACO & Occupational (status) & 16 & $\begin{array}{l}\text { Sector \& oc- } \\
\text { cupation }\end{array}$ & $\begin{array}{l}\text { Several mergers announced for } \\
2006\end{array}$ \\
\hline UK & 1 & TUC & & 71 & $\begin{array}{l}\text { Occupation \& } \\
\text { sector }\end{array}$ & $\begin{array}{l}\text { General unions as TUC affiliates; } \\
\text { small independent union sector }\end{array}$ \\
\hline $\mathrm{TR}$ & 3 & Türk-İş ;DİSK; Hak-İş & Political & 10 & Sector & 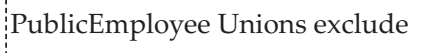 \\
\hline
\end{tabular}

* Macro-sector: for example industry, services or construction

Source: 25 Countries indicator plus Turkey 
might be international relations. In this field there are very sophisticated relations with European partners. A large majority of the unions and central organizations are affiliated to international federations such as ETUC, UNICE, ILO, (TUAC-BIAC) etc. Meanwhile they are very active in the international organization. Therefore representatives of almost all the organizations frequently participate to the international meetings. Some of them have close relations with international institutions and federations and also participate in EU institutions and projects. For instance all the trade unions which are affiliates of Türk-İș Confederation are member of the following international federations:

*In agriculture and wood sector IUF, IFBWW

*In mining, cement and petro-chemical sector ICEM, EMCEF

*In textile and leather sector ITGLWF, TCL

*In graphic, office and banking sector UNI

*In metal sector UAMIF

*In transport sector ITF

*In public sector PSI and EPSU

Trade unions affiliated to the other confederations are also members of some of these international federations.

\subsubsection{Personnel Capacity}

Personnel capacity is as much as European countries' unions. The only problem is lack of qualified personnel in some departments. On the other hand all experts' abilities are perfect such as speaking European languages, use computer and e-mail etc. The level of capacity shown in Table 6 (Öke, 2006).

\subsubsection{Financial Capacity}

The main resources of trade unions consist of membership fees for trade unions. The check-off system is the normal instrument to collect membership fees. The central organisations of trade unions usually have no fi-

\section{Table 6}

Personnel of trade union confederations

\begin{tabular}{|c|c|c|c|c|}
\hline 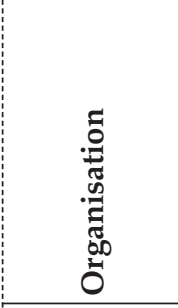 & 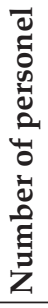 & 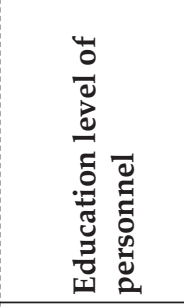 & 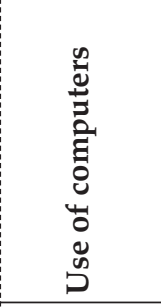 & 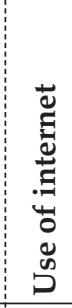 \\
\hline Türk-İş & 82 & $\begin{array}{l}\text { University/ } \\
\text { High School }\end{array}$ & Almost all & Yes \\
\hline Hak-İş & 31 & $\begin{array}{l}\text { University/ } \\
\text { High School }\end{array}$ & Almost all & Yes \\
\hline Disk & 12 & University & Almost all & Yes \\
\hline Tisk & 24 & University & Almost all & Yes \\
\hline Memur-Sen & 4 & University & Almost all & Yes \\
\hline KESK & 22 & University & Almost all & Yes \\
\hline Kamu-Sen & 10 & University & Almost all & Yes \\
\hline
\end{tabular}

Source: Sectoral and company level dialogue at Turkey, EU Foundation publication

nancial problems. There is no tradition of financial support by government or any other institutions and no regular external resources in Turkey. Unions and central organisations are able to cover all of their expenses.

In fact due to check off system finalcial situation is relatively good. Only Public Employee Unions have some financial problems. Additionally some of the unions have some properties in order to use for members such as education centre, holiday facility etc.

\subsection{External Factors Related To Lack Of Ca- pacity}

The foundations of trade unions in all European countries have been shaken by far reaching technological, economic and socio cultural changes since the seventies. Tha traditional trade union structure based on the 
standart employment relationship has been thrown into crisis by the recession and continuing mass unemployment. The social trend to more individualism has led to an increasing change in the objectives of trade unionist. Gainful employment is no longer the sole focus of the individual's identity; lifestyles and work patterns are being transformed, and the relationship between the sexes and between the generations is undergoing radical change. Growing social diversity among employees has resulted in the dissolving of professionally-based communities and class structures. This means that solidarity under its previous form can no longer function as a basis for the unified and effective mobilisation of trade unionist.(Müchenberger-Stroh-Zolf, 1995).

\subsubsection{Post-Fordism}

There are some external factors which led to industrial relations pattern. This changing process effected labour and labour organizations directly. In this sense the first shock was post fordism for the labour in the last decades. It was shock because blue colour workers replaced with white colour workers in the manifacture industry. The importance of this process for labour organizations are loss ground at the work place due to based on blue colour workers. In fact blue color workers were locomotive of trade union mouvement at all over the world. Additionally in this process robotic technology stimulated negative effects on labour and labour organizations.

European unions defend in many countries the group of semi skilled or unskilled labour, relatively high wage earner core workers, having socil protection in the labour market as member of trade union for long years.(Hyman, 1997)

\subsubsection{Globalization}

The second shock is undoubtly globalization for labour and labour organizations. As Peter Waterman says" labour worldwide in the era of globalisation is, undoutedly, in difficult straits. The trade union movement internationally has been increasingly stymied or peripheralised by a series of increasingly interlocking crises. One is the ongoing world economic crisis" (Waterman,1998)

Gradually globalization demonsrated to national economies and companies to be competitive in the global willage as a one way. To be competitive means; reduce the labour cost, the way of reducing labour cost is avoiding collective bargain and get rid of trade unions from the company and decrease wages and stabilising poor working conditions. Finally as a external factor globalization affected trade unions directly. At the end of process unions lost ground, membership, prestiges in the labour market. This reality valid not only for Turkey but also European countries as well. The trend in union density is clearly downward across Europe. Most of the EU Member States experienced a fall in density over 1995-2004. Especially unions in Eastern Europe have been confronted with dramatic membership losses: Hungary (75 points); Poland (55 points), Estonia and Czech Republic around 50 points, etc (Gyes, 2006)

Due to global competition main streams shifted to "protection of work place" from "protection of labour". Which means that undermined of labour law and social policy at this time.

Finally, the most influential effects of globalisation include the following:

flexibilisation of labour markets;

increasing labour migration;

rising atypical and non-standard forms of employment;

changes in work content and working conditions;

skills mismatch, multi-skilling and the need for lifelong learning (European Foundation, 2007).

\subsubsection{Neo-Liberal Polices}

Since 1980' the last and ongoing extenal effect is neo liberal policies. There are some direct results on labour and labour organizations. One of them due to termina- 
tion of contract losing the job. Secondly poor wages and poor working conditions. Thirdly the deleterious effect on labour and unions of the economic policies. At the macro level efects may be summarize as follow: Collective agreements decentralised, public service have been commercialized and deregulated. End of these policies; citizens shifted to client; public service shifted to market domination. Most radical changing happen in the nature of state. Regulatury system shifted to deregulation.

\subsubsection{Nature of Trade}

This uneven transition has changed the nature of trade. Capitalist economy has been rulling by Trans National Companies more than national economies. The speed of accumulation and mobility of capital emerged single centr system with the support of Bretton Woods Association.

During this process economic theory reversed and Trans National Companies made big profit while decreasing employment. Naturaly new system effected industrial relations sub system, scales and dimensions of enterprises have been changed.

Meanwhile structure and compozition of employment have been changed. Former labour market shifted with informel labour market and full time job shifted with casual work. All of this transformation put intensive pressure on trade unions. The choise is either support of interest of company or expecting get rid of the work place.

Finally cultural aspect may be add this factors, it is not sharing the solidarity value of young generation with their father.

\section{INDUSTRIAL DEMOCRASY AND REPRESENTATION}

The cause of Industrial Democrasy has a long history in Europe. In some countries on mainland Europe it can even be traced back to the early days of the first industrial revolution. Many European trade union mouvement stimulated a wide-ranging public debate on what kind of institutional representation workers should enjoy inside the business enterprises which employed them. But from the beginning important differen- ces of opinion existed between and within European countries and trade unions on what active and positive role workers might play in the internal affairs of companies without challenging the existance of private ownership of the means of production, distribution and Exchange.

The form and manner in which employee interests are represented either by trade unions or an institution elected by all employees, is a central factor in shaping the context for the individual employee's primary experience of social relations at the work place.

Trade Unions in the United Kingdom and the Scandinavian countries secured important and effective legal protections from the state so they were free to develop as independent collective bargainers through negotiations with employers on the improvement of the wages and conditions of their members and indirectly of workers who didn't belong a trade union. But the demand for direct reprasantation for workers or trade unions on the boards of private companies was not an important trade union priority. Trade Unions did not believe that they should become involved in the decision-making processes in firm at the highest level.

In other European countries most notably Germany, after war argued that such an ambitious objective should become an important and integral part of a much wider programme of workplace democracy for the labour mouvement that would evantually evolve into the creation of a planned market economy where organised workers came to excircise a dominant control over the forces of private capital.(Taylor, 2005)

\subsection{Information and consultation at the workplace}

Forms of information and consultation at the workplace have been legally established and formally installed in most of the EU countries. This workplace representation can be organized by works councils and/or trade union representatives. An extreme form of indirect participation is board-level representation. Laws in many European countries 
distinguish between three levels of influence: (1) information, (2) consultation and (3) joint decision-making or co-determination. In the majority of the EU countries there is a legal obligation to inform and consult with these institutionalised bodies on a range of matters. Only in the UK and Ireland does this kind of employee participation exist solely on a voluntary basis.

\subsection{Institutional setting}

In recent years several EU15 states revised their institutional arrangement of employee information and consultation rights at the workplace. New EU directives played a stimulating role in this processes (especially in the UK). These directives are also a major incentive for the accession countries to set up forms of workplace representation. Table belowed summarises the legal prescriptions on these forms of 'industrial democracy' for the EU-15. Indirect participation or employee representation is traditionally associated with trade unions. However, the involvement of union representatives is not the only channel of indirect participation. Other forms of indirect participation exist in a number of European countries, notably works councils. Rogers and Streeck (1994, p. 98) define works councils as "representative bodies elected by all workers at a particular workplace, regardless of union membership and inclusive of white-collar and many supervisory employees". Works councils are usually composed of employee representatives, but they may also include the employers' side.

Single-channel worker representation by trade union organisations is the dominant formalised type of indirect participation in Sweden, Ireland, and the UK. In this situation, the manner in which trade union representatives are elected or appointed depends upon each individual trade union (ETUCO, 2003). The works council can also be the primary body of worker representation at company level (as in Germany, Austria, the Netherlands, and Luxembourg). The extent of trade union representation on these bodies will depend on the ability of the unions to present candidates for election. In large German companies, for example, the works council tends to be dominated by trade union representatives.

Workers' interests can furthermore be taken into account by a two-channel system, where there is a works council operating alongside the trade union representatives:

the works council may simply represent all the different trade union organisations present in the company. In this case the existence of a works council does not release the employer from the obligation to deal and negotiate with the union organisations (Finland and Denmark);

the works council may exist alongside the trade union representations and have its own functions and powers. In France, for example, the recognised trade union organisations have a monopoly on the presentation of candidates in the first round of works council elections. Lists of independent candidates can be submitted at the second round stage, though only if the trade union lists have failed to win $50 \%$ of the vote. In Belgium and Spain, the works councils can be considered as bodies that complement the work of the company's trade union organisations.

Works councils are a joint body of management and employee representatives in Denmark, Luxembourg, Belgium and France (in addition to the autonomous representation body of employee delegates in France). In the two latter countries the employer chairs the works council.

Institutionalisation of workplace representation is still (to a large extent) under construction in the new Member States. The new European Information and Consultation directive has functioned as an additional pullfactor in recent years to stimulate new rules and regulations. Nonetheless, CEE trade unions are very often in widespread opposition to the introduction of works councils which they see as a dangerous competitive body instead of a useful support (with the exception of Slovenia and Hungary), (Gyes and others, 2006). 
Table 6

Legal provisions of workplace representation in EU-25

\begin{tabular}{|c|c|c|c|c|c|}
\hline & Bodies & Main body & Composition & Legal basis & Threshold \\
\hline $\mathrm{AT}$ & Works council & $\begin{array}{l}\text { Dual channel, } \\
\text { works council } \\
\text { dominates }\end{array}$ & $\begin{array}{l}\text { Workers' } \\
\text { representatives } \\
\text { only }\end{array}$ & Legislation & 5 \\
\hline $\mathrm{BE}$ & $\begin{array}{l}\text { Trade union delegates } \\
\text { Health\&safety committees } \\
\text { Works council }\end{array}$ & $\begin{array}{l}\text { Dual channel, trade } \\
\text { union dominates } \\
\text { works council }\end{array}$ & $\begin{array}{l}\text { Mixed } \\
\text { composition: } \\
\text { Management \& } \\
\text { Workers } \\
\end{array}$ & $\begin{array}{l}\text { Legislation and } \\
\text { collective } \\
\text { agreement }\end{array}$ & $\begin{array}{l}\text { Ranging from } \\
20-50 \\
50 \\
100\end{array}$ \\
\hline $\mathrm{CY}$ & Trade union delegates & $\begin{array}{l}\text { Single channel, } \\
\text { trade union }\end{array}$ & $\begin{array}{l}\text { Workers' } \\
\text { representatives } \\
\text { only }\end{array}$ & Legislation & \\
\hline $\mathrm{CZ}$ & $\begin{array}{l}\text { Trade union delegates } \\
\text { Works council possible* }\end{array}$ & $\begin{array}{l}\text { Single channel: } \\
\text { rare exception }\end{array}$ & $\begin{array}{l}\text { Workers' } \\
\text { representatives } \\
\text { only }\end{array}$ & Legislation & $\begin{array}{l}25 \text { (works } \\
\text { council) } \\
3 \text { (TU } \\
\text { representation) }\end{array}$ \\
\hline DK & $\begin{array}{l}\text { Shop stewards } \\
\text { Cooperation committees } \\
\text { Health and safety committees }\end{array}$ & $\begin{array}{l}\text { Dual channel, trade } \\
\text { union dominates } \\
\text { works council }\end{array}$ & $\begin{array}{l}\text { Mixed } \\
\text { composition: } \\
\text { Management \& } \\
\text { Workers }\end{array}$ & $\begin{array}{l}\text { Collective } \\
\text { agreement }\end{array}$ & 35 \\
\hline $\mathrm{EE}$ & $\begin{array}{l}\text { Trade union representation } \\
\text { workers trustee }\end{array}$ & $\begin{array}{l}\text { Single channel (in } \\
\text { practice) } \\
\text { or/ and non- } \\
\text { unionised trustee }\end{array}$ & $\begin{array}{l}\text { Workers' } \\
\text { representatives } \\
\text { only }\end{array}$ & Legislation & $\begin{array}{l}5 \text { (trade union } \\
\text { and/or } \\
\text { workers trustee) }\end{array}$ \\
\hline EL & $\begin{array}{l}\text { Works council } \\
\text { Employee representatives }\end{array}$ & $\begin{array}{l}\text { Dual channels } \\
\text { exists alongside }\end{array}$ & $\begin{array}{l}\text { Workers' } \\
\text { representatives } \\
\text { only }\end{array}$ & Legislation & $\begin{array}{l}50 \\
20\end{array}$ \\
\hline $\mathrm{DE}$ & Works council & $\begin{array}{l}\text { Dual channel, } \\
\text { works council } \\
\text { dominates }\end{array}$ & $\begin{array}{l}\text { Workers' } \\
\text { representatives } \\
\text { only }\end{array}$ & Legislation & 5 \\
\hline FI & $\begin{array}{l}\text { Cooperation committee or } \\
\text { negotiation }\end{array}$ & $\begin{array}{l}\text { Dual channel, trade } \\
\text { union dominates } \\
\text { works council }\end{array}$ & $\begin{array}{l}\text { Mixed } \\
\text { composition: } \\
\text { Management \& } \\
\text { Workers }\end{array}$ & $\begin{array}{l}\text { Legislation and } \\
\text { collective } \\
\text { agreement, no } \\
\text { compulsory } \\
\text { system }\end{array}$ & 30 \\
\hline FR & $\begin{array}{l}\text { Employee delegates } \\
\text { Works council } \\
\text { Trade union delegates } \\
\text { Health and safety committees }\end{array}$ & $\begin{array}{l}\text { Dual channels } \\
\text { exists alongside }\end{array}$ & $\begin{array}{l}\text { Mixed } \\
\text { composition: } \\
\text { Management \& } \\
\text { Workers }\end{array}$ & Legislation & $\begin{array}{l}11 \\
\vdots \\
50\end{array}$ \\
\hline $\mathrm{HU}$ & $\begin{array}{l}\text { Works council } \\
\text { Trade union representation }\end{array}$ & $\begin{array}{l}\text { Dual channel } \\
\text { works council } \\
\text { dominates (esp. in } \\
\text { cases of TU } \\
\text { pluralism) }\end{array}$ & $\begin{array}{l}\text { Workers' } \\
\text { representatives } \\
\text { only }\end{array}$ & Legislation & $\begin{array}{l}15 \text { (one person)/ } \\
50 \text { (works } \\
\text { council) }\end{array}$ \\
\hline IE & Trade union representation & $\begin{array}{l}\text { Single channel, } \\
\text { trade union }\end{array}$ & $\begin{array}{l}\text { Workers' } \\
\text { representatives } \\
\text { only }\end{array}$ & $\begin{array}{l}\text { Collective } \\
\text { agreement, } \\
\text { voluntary; } \\
\text { minimalist legal } \\
\text { framework in } \\
\text { stage of } \\
\text { enactment }\end{array}$ & \\
\hline IT & $\begin{array}{l}\text { Elected/nominated trade } \\
\text { union representative bodies }\end{array}$ & $\begin{array}{l}\text { Dual channel, trade } \\
\text { union dominates } \\
\text { works council }\end{array}$ & $\begin{array}{l}\text { Workers' } \\
\text { representatives } \\
\text { only }\end{array}$ & $\begin{array}{l}\text { Legislation and } \\
\text { collective } \\
\text { agreement }\end{array}$ & 15 \\
\hline $\mathrm{LU}$ & & $\begin{array}{l}\text { Dual channel, trade } \\
\text { union dominates } \\
\text { works council }\end{array}$ & $\begin{array}{l}\text { Mixed } \\
\text { composition: } \\
\text { Management \& } \\
\text { Workers } \\
\end{array}$ & Legislation & \\
\hline LV & $\begin{array}{l}\text { Trade union representation } \\
\text { Employees' council possible } \\
\text { ingen }\end{array}$ & $\begin{array}{l}\text { Dual channel } \\
\text { (works council as } \\
\text { rather rare } \\
\text { exception) }\end{array}$ & $\begin{array}{l}\text { Workers' } \\
\text { representatives } \\
\text { only }\end{array}$ & Legislation & 5 (works council) \\
\hline LT & $\begin{array}{l}\text { Trade union delegates } \\
\text { Works council possible } \\
\text { (Czech model): }\end{array}$ & $\begin{array}{l}\text { Single channel } \\
\text { (dual channel for a } \\
\text { limited time) }\end{array}$ & $\begin{array}{l}\text { Workers' } \\
\text { representatives } \\
\text { only }\end{array}$ & Legislation & $\begin{array}{l}20 \\
\text { (employees' } \\
\text { council) }\end{array}$ \\
\hline
\end{tabular}


Table 6 (continue)

Legal provisions of workplace representation in EU-25

\begin{tabular}{|c|c|c|c|c|c|}
\hline MT & $\begin{array}{l}\text { Trade union representation } \\
1 \text { works council elected in } \\
2005\end{array}$ & $\begin{array}{l}\text { Single channel } \\
\text { (usual practice) }\end{array}$ & $\begin{array}{l}\text { Workers' } \\
\text { representatives on }\end{array}$ & $\begin{array}{l}\text { Legislation;a } \\
\text { non-mandatory } \\
\text { shop agreement } \\
\text { between TUs }\end{array}$ & \\
\hline NL & $\begin{array}{l}\text { Works council } \\
\text { Employee representation }\end{array}$ & $\begin{array}{l}\text { Dual channel, } \\
\text { works council } \\
\text { dominates }\end{array}$ & $\begin{array}{l}\text { Workers' } \\
\text { representatives } \\
\text { only }\end{array}$ & Legislation & $\begin{array}{l}50 \\
10\end{array}$ \\
\hline PL & $\begin{array}{l}\text { Trade union representation } \\
\text { works council in state owned } \\
\text { companies }\end{array}$ & Single channel ${ }^{* * *}$ & $\begin{array}{l}\text { Workers' } \\
\text { representatives on }\end{array}$ & Legislation & $\begin{array}{l}100 \text { (draft act of } \\
\text { government } \\
2004)^{* * *}\end{array}$ \\
\hline PT & Workers' committee & $\begin{array}{l}\text { Dual channels } \\
\text { exists alongside }\end{array}$ & $\begin{array}{l}\text { Workers' } \\
\text { representatives } \\
\text { only }\end{array}$ & Legislation & None \\
\hline SK & $\begin{array}{l}\text { Trade union representation } \\
\text { Works council }\end{array}$ & $\begin{array}{l}\text { Dual channel, but } \\
\text { works council rare } \\
\text { exception }\end{array}$ & $\begin{array}{l}\text { Workers' } \\
\text { representatives on }\end{array}$ & Legislation & $\begin{array}{l}5 / 50 \text { (works } \\
\text { council) } \\
5 \text { (trade union) }\end{array}$ \\
\hline SI & $\begin{array}{l}\text { Works council } \\
\text { Trade union representation }\end{array}$ & $\begin{array}{l}\text { Dual channel } \\
\text { works council } \\
\text { slightly more } \\
\text { frequent }\end{array}$ & $\begin{array}{l}\text { Workers' } \\
\text { representatives on }\end{array}$ & Legislation & $\begin{array}{l}20 \text { (works } \\
\text { council) }\end{array}$ \\
\hline ES & Works council & $\begin{array}{l}\text { Dual channels } \\
\text { exists alongside }\end{array}$ & $\begin{array}{l}\text { Workers' } \\
\text { representatives } \\
\text { only }\end{array}$ & Legislation & 50 \\
\hline SE & Trade union representation & $\begin{array}{l}\text { Single channel, } \\
\text { trade union }\end{array}$ & $\begin{array}{l}\text { Workers' } \\
\text { representatives } \\
\text { only }\end{array}$ & $\begin{array}{l}\text { Collective } \\
\text { agreement }\end{array}$ & None \\
\hline UK & Trade union representation & $\begin{array}{l}\text { Single channel, } \\
\text { trade union }\end{array}$ & $\begin{array}{l}\text { Workers' } \\
\text { representatives } \\
\text { only }\end{array}$ & $\begin{array}{l}\text { Collective } \\
\text { agreement, } \\
\text { voluntary with } \\
\text { minimalist legal } \\
\text { framework since } \\
2005\end{array}$ & 50 , undertakings \\
\hline
\end{tabular}

* Alternative "Czech model: either trade union or a works council may exist (the latter must stop its activities if a union representation is elected in a company).

**elected by all employees (in non unionised companies), as rare exception. In 2005 the Estonian government sent a draft of an Employees' Representatives Act to the social partners with a dual channel representation to implement the Directive on information and consultation which found no approval by them.

*** In privatised enterprises by law (in state owned enterprises still exist some works councils). In 2004 the Polish government proposed to introduce a dual channel model but the social partners are more in favour of the Czech model: No decision as yet

Source: Country profiles

\subsection{Representation in Turkey}

Main pillars of the European Social Model is based on minimal standards of EU, social dialogue in the field of working time, mass dismissal, European works councils, information and consultation participation of workers in supervisory boards etc. to be implemented at

- company level by a workplace representation (incl. EWCs)

- by collective negotiations at enterprise and sectoral level
- by tripartite social concertation between government and the social partners

- by instruments of mediation, conciliation and arbitration

- by the control of social partners, the labour inspection and effective judicial control

Turkey as a acceding country, shoul have realized the main pillars of social model, unfortunately it is bit behind where should be. At national level there is tripartite social dialo- 
gue mechanism. It is economic and social council. ESC is one of the main multi-party social dialogue mechanisms between various social groups and government in Turkey. It was set up by the Law No 4641 dated 2001. However previously, irregular meetings had been held since 1995, by decrees issued by the various governments to satisfy the broadbase social dialogue needs. Meanwhile Turkey ratified ILO Convention No: 144, Tripartite Consultations to promote the Implementation of ILO standards on 1993. resentatives are not regulated by our legislation. However, consultation takes place on certain issues between the employer and representatives of the trade union authorized to bargain collectively.

There is single-tier employee participation system in Turkey and union monopoly is occured at workplaces and undertakings which is not equal to EU two-tier employee participation system.(Özcüre, 2009)
Main duities of ESC; to ensure the participation of the various social partners in the governmental economic and social policies. To promote consensus and cooperation both between the government and these groups and among these groups themselves. To present, on Government's referral, opinions on the law proposals on various economic and social matters that are related to the economic and social life, and Development Plans and Annual Programmes.

With the Labour Law (No. 4857, Art. 114), the Tripartite Consultation Board was established to ensure effective consultation between the government and confederations of employers', workers' and public servants' unions, with a view to promoting labour peace and industrial relations, as well as enabling the social partners to monitor preparation and implementation of legislation on labour life.

At national level, there is no bipartite social dialogue platform. At sectoral level, although it is not common, bipartite consultation practices have been launched by workers and employers organizations in the sectors of metal, textile, construction and cement, in the form of joint actions, primarily in the field of vocational training. Turkey has ratified ILO Convention No. 135 on Workers' Representatives in 1971.

European Work Councils and Workers' rep-
Workplace representation by unions or works councils and TU density in the new EU member states ( $\%$ of all employees)

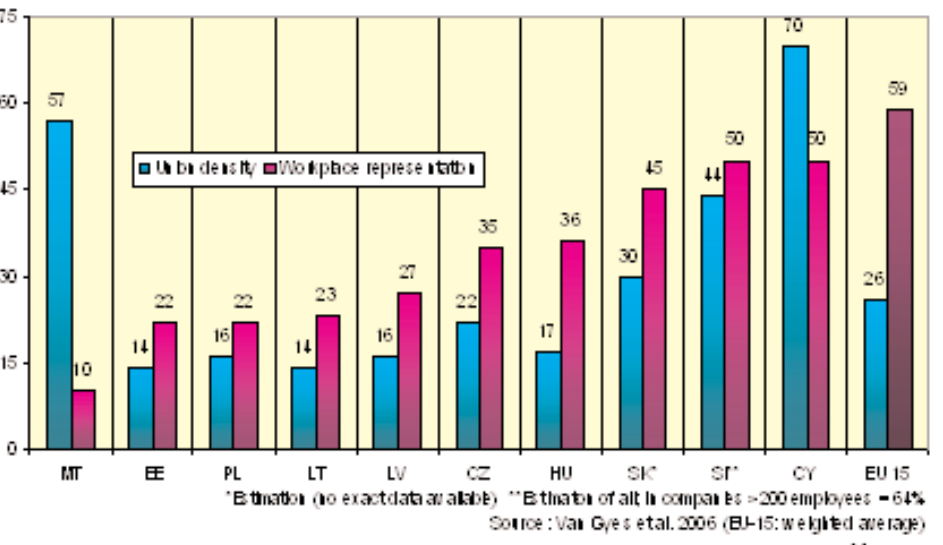

\section{Conclusion}

EU directive 2002/14/EC require information and consultation bodies in order to realize minumum standarts and cohesion at the work. This function maintain by trade union if trade union unpresent in this case this service delivered by employee representative. Table above indicate both union and employee representation in the new EU member countries.

None of the enterprise has any information, consultation or joint decision making body in the labour market except some committees which created by collective agreement.

Workers' interests taken into account by single channel system in Turkey. It is union represantation. Therefore there is very close link between the representation and existance of union. In the other words if there is not union 
organization at the company almost there is no body in order to defend interest of workers. There is some exception in the public sector but geneally it is linked to union existance. Naturally there is no sense to say something about small scale enterprises and informal economy in the field of representation or defending interest of workers.

The other way might be a chance for workers, it is work councils at large enterprises. EU directives put pressure on this issue and observing some initial experience in the industrial relations arena. On the contrary of Nordic Countries there is very weak represantation performance in Turkey. The presence of representation connected to union and collective bargain. Low rate of union density and weak connection between density and collective agreement coverage emerge limit in the effectiveness and efficiency of union.

Labour Ministry attemp to some projects and activities in order to improve tripartite social dialogue and bipartite dialogue among the industrial relations actors but both sides hesitate take part jointly. Because especially social actors to distrust for goverment, due to performance of Economic and Social Council. It is true regulation has been changed, body has been set up by goverment but considering the role of ESC in the economic and social policy is only cosmetic. So actors expecting not so much from tripartite or bipartite dialoge mechanism.

Recently one of the capacity building project has been launched by Labour Ministry which funded by EU Commission claims to strengthening institutional capacity of MoLSS and social partners in the social field on the road to EU accession. Many projects realized in the field of indutrial relation but result is not very optimistic.

Finally, there are some steps should be taken in the field of institutionalise of representation and social dialogue. In order to achieve this target trade unionism should be taken as a vehicle for social integration as Hyman said. Otherwise not only industrial relation system but also economic and political system will be suffer much more.

\section{REFERENCES}

Asp, Ulf (2002) "The Trade Union Situation in Turkey", South East Europe Review (SEER), Volume 5, Number 3 Baden Baden

ETUCO (2003), Worker representation systems in the European Union and the accessioncountries, Brussels: Etuco.

European Foundation, (2007) Impact of Globalisation on Industrial Relations in the EU and Other Major Economies, Dublin

Gyes Van Guy, Tom Vandenbrande, Steffen Lehndorff, Gabi Schilling, Sebastian Schief, Heribert Kohl (2006) "A basic comparison of 25 national systems; report of the project "Quality of industrial relations: comparative industrial relations country profiles in the EU Member States" Industrial relations in the Member States of the European Union Synthesis commissioned by the European Foundation for the Improvement of Living and Working Conditions, Leuven, 2006

Hülsmann, Joachim-Kohl Heribert, (2006) Social Dialogue Capacity Building, Workshop Ljubliana, March 2006

Hyman, Richard (1997), “Küreselleşme Kapsamında Sendikalar ve Çıkar Temsili", Transfer, Volume 3 Number 3

Kohl Heribert and Platzer Hans-Wolfgang (2004) "Workplace Industrial Relations and Employee Representation", Industrial Relations in Central and Eastern Europe, ETUI Publication, Brusells

Koray, M. (1992) The industrial relations system in Turkey: developments, problems and expectations, İstanbul: Friedrich Ebert Foundation 
Müchenberger Ulrich; Conny Stroh; Rainer Zolf (1995)"'The Challenge of Modernization: Towards a new paradigm for trade unions in Europe", Transfer, Volume 1 Number 1, Brussels

Öke, M.Kemal ; Güray, M. (2007) “Capacity building for social dialogue at sectoral and company level in Turkey" European Foundation for the Improvement of Living and Working Conditions. http://www.eurofound.europa.eu/pu bdocs/2007/2214/en/1/ef072214en.pd $f$, Dublin Ireland

Öke, M.Kemal;(2006) “Capacity building for social dialogue in Turkey" Eurofound Publication,Dublin, http:// eurofound.europa.eu/publications/htmlfiles/ef06511.htm

Öke, M.Kemal (2005) “Employment and Social Dialogue in Turkey from the Perspective of EU Integration", in The Enlargement of Social Europe-The Role Of Social Partners In The European Employment Strategy-Part II, SALTSACREER-ESC-ETUI, Brussels.

Özcüre, G; Demirkaya, H; Eryiğit, N; Yüce, G (2009) "The Influence Of The European Union Employee Participation System And Related Acquis On The Companies Operatıng In Turkey" South East Europe Review (SEER), 2009

Rogers J. \& Streeck W. eds. (1995), Works councils, consultation and cooperation in industrial relations, New York: University of Chicago Press.

Taylor, Robert (2005) “Industrial Democrasy and the European Tradition", Transfer, Volume 11 Number 2, Brussels

Waterman, Peter(1998) Labour Worldwide in the Era of Globalisation: Alternative Union Models in the New World Order. Editing book. Peter Waterman and Ronaldo Munck, co-editors. 